\title{
Hydric Attenuation of a Green Roof Experimental Assembly in Bogotá*
}

\section{Atenuación Hídrica en techos verdes, caso de estudio Bogotá}

\section{Atténuation Hydrique dans les plafonds verts, cas d'étude Bogota}

\author{
Nicolás Oviedo**, Andrés Torres***, Carlos Devia****, Angela Puentes*****
}

Recibido: 2015-06-10 // Aprobado: 2015-08-09 // Disponible en linea: 2016-01-30

Cómo citar este artículo: Oviedo, N., Torres, A., Devia, C. y Puentes A. (2016). Hydric Attenuation of a Green Roof Experimental Assembly in Bogotá. Ambiente y Desarrollo, 20(38), 53-68. http:// dx.doi.org/10.11144/Javeriana.ayd20-38.hagr

doi:10.11144/Javeriana.ayd20-38.hagr

\begin{abstract}
In this study, the hydric attenuation of a green roof was assessed by using three indicators: lag-time, runoff coefficient, and water volume retention. Two types of plants -Pennisetum clandestinum and Melissa officinalis- and three substrate depths $(5,10$, and $15 \mathrm{~cm})$ for a total of 6 treatments with three replicates and seven rain events were registered. The experiments were carried on the top roof of the "Rafael Arboleda" building from Pontificia Universidad Javeriana, Bogotá Colombia (4 ${ }^{\circ} 37^{\prime} 43.33^{\prime \prime}, 74^{\circ} 03^{\prime} 46.04^{\prime \prime}$ ) at 2633 meters above sea level. Maximum lagtimes and runoff equivalent ratios of 70 minutes and 0.1 respectively, as well as a maximum volumetric percentage retention close to $100 \%$ were obtained. However, important variabilities of these results were observed, which were analyzed by using
\end{abstract}

* This researching project: Hydric attenuation of a green roof experimental assembly in Bogotá, was directed by the $\mathrm{PhD}$ Andres Torres, researcher from Ciencia e Ingeniería del Agua y el Ambiente, of the Department of Civil Engineering, Pontificia Universidad Javeriana. This project had been supported with internal funding from November 2011 to April 2012.

** Civil Engineering and Researcher from Ciencia e Ingeniería del Agua y el Ambiente. Department of Civil Engineering, Pontificia Universidad Javeriana, Bogotá, Colombia. E-mail: d.oviedo@javeriana.edu.co

*** Ph.D. in Urban Hydrology, Researcher from Ciencia e Ingeniería del Agua y el Ambiente. Department of Civil Engineering, Pontificia Universidad Javeriana, Bogotá, Colombia. E-mail: andres.torres@javeriana.edu.co

**** Ph.D. Candidate in Engineering, Researcher from Grupo de Investigación de Ecología y Territorio. Department of Ecology and Territory, Pontificia Universidad Javeriana, Bogotá. Colombia. E-mail: cdevia@ javeriana.edu.co

***** MS.c. in Hidrosistemas and Researcher from Ciencia e Ingeniería del Agua y el Ambiente. Department of Civil Engineering, Pontificia Universidad Javeriana, Bogotá, Colombia. E-mail: angela.puentes@javeriana.edu.co 
multiple correspondence analysis and Anova: the type of plant and hydrological characteristics of the rainfall event (duration, maximum intensity, mean intensity, level drained) have significant influence on these variabilities.

Keywords: runoff coefficient; green roof; Kernel estimators; flooding probabilities

\section{Resumen}

En este estudio se evaluó la atenuación hídrica de un techo verde utilizando tres indicadores: lag-time, coeficiente de escorrentía y volumen de agua retenida. Se registraron siete eventos de lluvia y se evaluó su respuesta para dos tipos de plantas -Pennisetum clandestinum y Melissa officinalis - y tres profundidades de sustrato (5, 10 y $15 \mathrm{~cm}$ ), para un total de seis tratamientos con tres repeticiones. Los experimentos se realizaron en el techo del edificio "Rafael Arboleda" de la Pontificia Universidad Javeriana, Bogotá Colombia (4³7'43 .33", 74 '03'46.04 ") a 2633 metros sobre el nivel del mar. Máximos lag-time y coeficientes de escorrentía de 70 minutos y 0,1, respectivamente. De la misma manera, se observaron volúmenes de retención máximos cercanos al 100\%. Sin embargo, se evidenciaron variabilidades importantes de estos resultados, los cuales se analizaron utilizando el análisis de correspondencias múltiples y Anova: el tipo de planta y las características hidrológicas del evento de lluvia (duración, intensidad máxima, intensidad media, nivel de drenado) tienen influencias significativas sobre estas variabilidades.

Palabras clave: coeficiente de escorrentía; techo verde; Estimadores Kernel; las probabilidades de inundación

\section{Résumé}

Dans cette étude on a évalué l'atténuation hydrique d'un plafond vert en utilisant trois indicateurs : lag-time, coefficient du ruissellement et volume d'eau capté. On registré sept évènements de pluie et on a évalué la réponse pour deux types de plants -Pennisetum clandestinum y Melissa officinalis - et trois profondeurs de substrat $(5,10$ y $15 \mathrm{~cm})$, au total de six traitements avec trois répétitions. Les expérimentés ont étés réalisés dans le plafond du bâtiment "Rafael Arboleda» de la Pontificia Universidad Javeriana, Bogotá Colombie (4³7' 43 .33'”, 74 $03^{\prime} 46.04$ ") à 2633 mètres au-dessus du niveau de la mer. Maximal lag-time et coefficient de ruissellement de 70 minutes et 0,1 , respectivement. De la même façon on a observé volumes de captation maximaux proches au 100\%. Cependant, on a observé changements importants de ces résultats, ceux-ci ont étés analysés en utilisant l'analyse de correspondances multiples y Anova: le type de plante et les caractéristiques hydrologiques de l'évènement de pluie (durée, intensité maximal, intensité moyenne, niveau de drainage) ont influences importantes sur ces variables.

Mots-clés: coefficient de ruissellement; plafond vert; estimateurs Kernel; les probabilités d'inondation 


\section{Introduction}

In urban catchments the hydrologic cycle is changing due to high level of human interference with natural processes, which is related with population growth (Niemczynowicz, 1999). This change is due mainly to the construction of impervious areas, leading to the decrease of the percentages of infiltration and increase of evaporation, which modify concentration times in an urban catchment. When concentration time decreases, the runoff flow has an important increase as a result of land-use change and implementation of sewer systems (Araújo \& González, 2010; Oberndorfer, Lundholm, Bass, Coffman, Doshi, Dunnett,... Rowe, 2007; Peck \& Callaghan, 2005). Around the 70's, as a solution to the change of hydrological cycle's fluxes in urban areas, the development of new techniques for the management of rainwater in urban areas, known as sudss (Sustainable Urban Drainage Systems), started in Europe. The sudss main objective is to reestablish the energy and matter flows present before the urbanization and improve the water quality.

Generally, suDs require a large space to be implemented, which could be considered as a disadvantage; nevertheless green roofs do not need new areas because they can be installed on the existing building roofs. For this reason green roofs have an advantage in comparison to other suds (Ballard \& Kellagher, 2007; CsQ, 2003). The green roofs have their ancient roots in the hanging gardens, which began in Semiramis, in what is now Syria (Oberndorfer et al., 2007). They were constructed with the main objective of decorating roofs. Nowadays, many of the green roofs have the same purpose (Oberndorfer et al., 2007), but during the last three decades, the green roofs have been developed as a solution to the problems related to urbanization mentioned above (U.S. Government, 1987; Werthmann \& C. Architects, 2007).

The green roofs performance has been related with rainfall levels through the runoff coefficient (Kasmin, Stovin, \& Hathway, 2010), the Antecedent Dry Weather Period (ADWP), the type of vegetation in terms of Lai and stomatal resistance and the soil used (Getter \& Rowe, 2006; Mentens, Raes, \& Hermy, 2006). Also, the soil composition and the layer depth have a significant effect on the mitigation of stormwater runoff; according to (Dunnett, Nagase, Booth, \& Grime, 2008) the depth of the soil layer and its weight have a significant negative correlation (pvalue $<0.05$ ), concluding that plants with deeper soil layer are associated with less runoff volumes. Other potential benefits include the enhancement of rain water quality through absorption and filtration of pollutants, such as some metals; a reduction of the urban heat-island effect; an increasing of wildlife in the city; a significant mitigation of temperature peaks; and the improvement of air quality (Li, Gong, Zhao, \& Liu, 2008; Marsalek, 2007).

Green roofs have been classified considering the height of the soil layer as follows (Ballard \& Kellagher, 2007; Mentens et al., 2006; New Jersey Department of Environmental Protection, 2004; Oberndorfer et al., 2007; Peck \& Callaghan, 2005; Werthmann \& C. Architects, 2007): (i) Extensive, with heights between $25 \mathrm{~mm}$ and $125 \mathrm{~mm}$, and daily maintenance requirements according to the function of the type of vegetation; (ii) Intensive, with more than $125 \mathrm{~mm}$ of height, and less maintenance requirements; (iii) Simple, which have the main objective of decorating urban spaces, and are commonly constructed with synthetic materials.

Several studies show the potential benefits achievable by recurring to roof vegetation (Ascione, Bianco, De’ Rossi, Turni, \& Vanoli, 2013; Tsang \& Jim, 2013). However, it is becoming increasingly well appreciated that the strength of these environmental benefits are dependent on the design of the green roof used and that more research is needed before these potential advantages are fully understood and quantified (Bates, Sadler, \& Mackay, 2013). For example, research about the mitigation of stormwater runoff in green roofs as a function of the plant species are limited and few papers recommend a combination of plant, soil, and depths for enhancing the green roofs performances. In addition, most of these results have been obtained by simulating the rain (Dunnett et al., 2008; Getter \& Rowe, 2006; Kasmin et al., 2010; Niemczynowicz, 1999). For this reason the scientific community does not know the behavior of green roofs when they are used in real and extreme weather conditions (for 
example extremes rainfall events and long dry periods). Hence, this work evaluates hydric attenuation on six green roof experimental assemblies. They were made of two different species (Gramineae (grass (Penisettum clandestinum) and Lamiaceae (Lemon balm (Melissa officinalis)), and three different depths $(5 \mathrm{~cm}, 10 \mathrm{~cm}$, and $15 \mathrm{~cm}$ ), with the same soil type, for real weather conditions in Bogota (Andean tropical climate).

\section{Methods}

The experiment design consisted of six treatments with three repetitions each one (for a total of 18 treatments), which corresponds to following factors: (i) Layer soil depth: $5 \mathrm{~cm}, 10 \mathrm{~cm}$, and $15 \mathrm{~cm}$; (ii) Kind of plant: Gramineae (grass (Penisettum clandestinum) and Lamiaceae (Lemon balm (Melissa officinalis).

Each treatment was carried out by a plastic container (rectangle area: $20 \mathrm{~cm} \times 30 \mathrm{~cm}$, height: 15 $\mathrm{cm}$ ) with a test tube connected to a hose. Each container had a $2 \mathrm{~cm}$ diameter hole in the bottom for drainage purposes. For comparison, a container without soil and plants was included, which was used as a reference.

The green roofs experimental assemblies were settled down in the top roof of the Jose Rafael Arboleda building (see Figure 1) at Pontificia Universidad Javeriana, in Bogota. We have recorded seven rainfall events, between November 2011 and April 2012. The procedure of measuring rainfall consisted in taking a picture of the test tubes set every minute during each rainfall event with a HD web cam with a resolution of 1080x1030 pixels (see Figure 2). After the pictures were taken, a time-stack was obtained for each rainfall event (Figure 3), using a MatLab script specially developed for this purpose. Figure 3 shows the runoff level variation in the treatment with Grass and $5 \mathrm{~cm}$ of layer soil depth measured on 11th of April 2012.

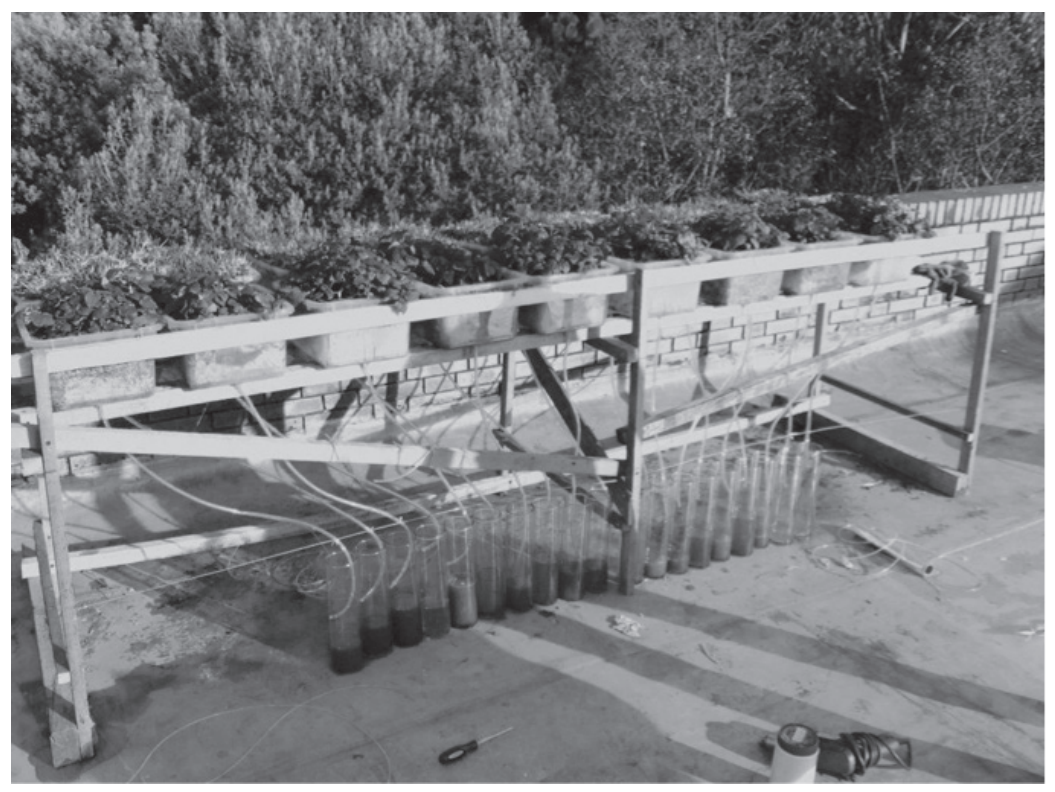

Figure 1. Photo of experimental assembly 
Source: authors

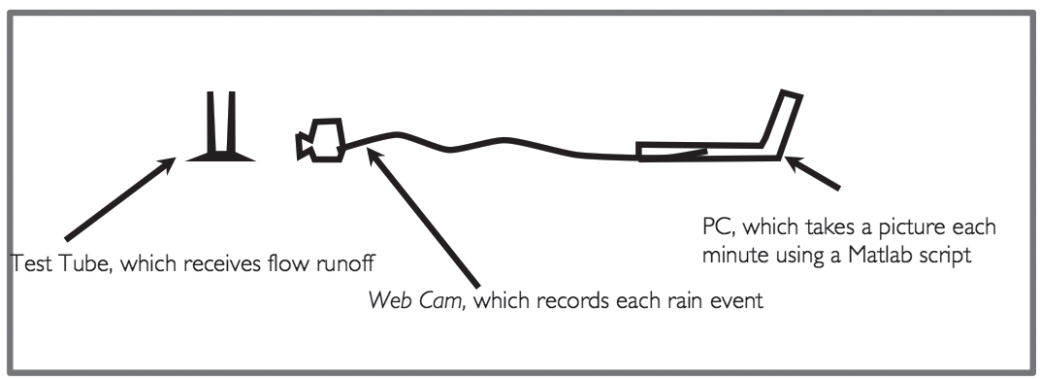

Figure 2. Scheme of the assembly for the recording of rainfall events Source: Authors

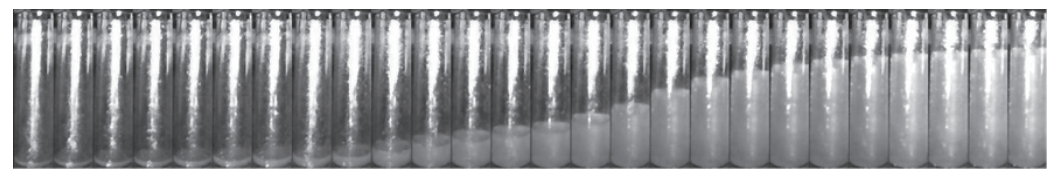

Figure 3. Example of time-stack for 11 th April 2012 rainfall event. Test-Tube $N^{\circ} 8$

Source: authors Pennisetum clandestinum

Fieldwork allowed the collection and analysis of 10 variables for each rainfall event recorded. Event ID, Maximum Intensity (Imax), Mean Intensity (Imean), Rainfall Depth, and Duration describe the hydrologic characteristics of each rainfall event recorded. Plant and Layer Depth define the green roofs while Volume Retain $(\mathrm{Vp})$, Lag Time $(\mathrm{K})$ and Runoff Coefficient $(\mathrm{C})$ explain the hydrological answer of each green roof to the rainfall event.

Multiple Correspondence Analyses (MCA) was applied with R (R Core Team, 2013) in order to identify relations between the variables measured explained above. For each dependent variable $(K, C$, and $\mathrm{Vp}$ ) a variance analysis (Anova) (Larson, 2008) was done with $\mathrm{R}$ (R Core Team, 2013) in order to establish the significance level of each independent variable over the hydric attenuation of the green roofs studied.

\section{Results}

As a summary, lag-times values obtained were under 70 minutes, minimum equivalent runoff coefficients obtained were 0.1 , and maximum percentage of retention volumes in the treatments were close to $100 \%$. Error: Reference source not found shows the main characteristics of each event recorded. As it can be seen in the appendix (Error: Reference source not found), the maximum values of retention volumes are presented in rainfall events with short durations (74 $\mathrm{min}$ and $83 \mathrm{~min}$ ).

Rainfall events 1, 3, 5, 7 in one hand and events 2, 4, 6 on the other hand presented similar behaviors regarding their rainfall responses. In the first group (rainfall events 1, 3, 5 and 7) the control's hydrographs presented the highest peak flow in the medium of each rainfall event while treatments' hydrographs do not show any peak flow in the same time (Figure 4). On the other hand, when the control's hydrographs present their highest peaks at the beginning and in the last part of the rainfall event as in the second group (rainfall events 2, 4 and 6) all treatments' hydrographs exhibit flow peaks in similar times. Hence it can be concluded that when an event has few flow peaks and the highest occur at the beginning of the rainfall event (e.g. rainfall events 2 and 6), the hydrological answers of the green roofs are very similar in terms of the time to peaks and have smaller runoff coefficients. In Table 2, it can be observed that the rainfall events 5 and 6 exhibit the highest retention volumes. It could be due to the fact that these rainfalls have the lowest intensities. As an example we show in Figure 4 the green 
Table 1. Characteristics of each Rainfall Event.

\begin{tabular}{ccccccc}
\hline $\begin{array}{c}\text { Rainfall } \\
\text { Event }\end{array}$ & $\begin{array}{c}\text { Event } \\
\text { Date }\end{array}$ & $\begin{array}{c}\text { Duration } \\
\text { [minutes] }]\end{array}$ & $\begin{array}{c}\text { Maximum } \\
\text { Intensity } \\
{[\mathrm{mm} / \mathrm{h}]}\end{array}$ & $\begin{array}{c}\text { Mean } \\
\text { Intensity } \\
{[\mathrm{mm} / \mathrm{h}]}\end{array}$ & $\begin{array}{c}\text { Total } \\
\text { Depth of } \\
\text { Rain Water } \\
{[\mathrm{mm}]}\end{array}$ & $\begin{array}{c}\text { Average } \\
\text { Depth of } \\
\text { Rain Water } \\
{[\mathrm{mm}]}\end{array}$ \\
\hline $\begin{array}{c}\text { 19th } \\
\text { November } \\
2011\end{array}$ & 133 & 28.96 & 6.36 & 14.31 & 10.32 \\
\hline 2 & $\begin{array}{c}27 \text { th } \\
\text { March } \\
2012\end{array}$ & 83 & 78.62 & 12.45 & 17.64 & 13.34 \\
\hline 3 & $\begin{array}{c}10 \text { th April } \\
2012\end{array}$ & 178 & 22.41 & 8.08 & 24.23 & 9.54 \\
\hline 4 & $\begin{array}{c}11 \text { th April } \\
2012\end{array}$ & 252 & 22.23 & 5.64 & 24.43 & 11.41 \\
\hline 5 & $\begin{array}{c}16 \text { th April } \\
2012\end{array}$ & 109 & 13.69 & 3.11 & 5.70 & 3.06 \\
\hline 6 & $\begin{array}{c}20 \text { th April } \\
2012\end{array}$ & 74 & 13.93 & 3.60 & 4.50 & 3.23 \\
\hline 7 & $\begin{array}{c}21 \text { th April } \\
2012\end{array}$ & 164 & 16.20 & 3.76 & 10.34 & 6.38 \\
\hline
\end{tabular}

Source: authors

roof answer to the $3^{\text {rd }}$ event.

Results of Multiple Correspondence Analyses (MCA) (R Core Team, 2013) are shown in Figure 5 , which was used to establish the possible relations between hydric attenuation and the hydrologic characteristics.

Four principal components were retained which explain $65 \%$ of the total variance. Figure 5 shows eight input variables (Event, Plant, Layer Depth $(L D)$, Maximum Intensity (Imax), Mean Intensity (Imean), Depth of Rain (Haverage), Duration (D), and Drain-Level). Event variable classifies the rainfall events in three groups ( $1^{\text {st }}$ group: 6,$5 ; 2^{\text {nd }}$ group: $7,2,1$; and $3^{\text {rd }}$ group: 3,4$)$ according to the distances to the first and second principal components. This result supports that each rainfall event shares characteristics with others, for example $1^{\text {st }}$ group and $2^{\text {nd }}$ group have less rainfall durations and heights, while $3^{\text {rd }}$ group presents the largest duration and Haverage values. Figure 5d) and Figure 5f) group Imax and Haverage in three categories (low, medium, and high), according to their importance in terms of the distance to the first and second principal components, while Figure 5e) and Figure 5h) classify Imean and Drain-level data in two groups following the distance to the first component (group 1: low and group 2: medium and high). This could indicate a relation between Drain-level and Imean. In the same way, Figure 5b) shows a clustering according to the presence or absence of plants on the roofs (without green roof: Plant $=$ control; with a green roof: Plant $=$ Melissa or Grass). Figure 5c) shows a classification of $L D$ data in two groups (without green roof: $L D=$ control; with a green roof: $L D=$ Melissa or Grass) according to their distances to the second principal component. Nevertheless, this analysis does not show any difference between layers depth, so we can conclude that $L D$ is not related with hydric attenuation through hydrologic characteristics. The output variables $C, K$, and $V p$ are divided into two groups, which are separated according, mainly, to their distances to the second principal component. We observe higher $C, K$, and $V p$ values for Melissa-Officinalis than for Pennisetum-Clandestinum. 
Likewise, the duration of the rainfall events, the mean, and the maximum intensities seem to have a high influence on $C, K$, and $V p$ results.

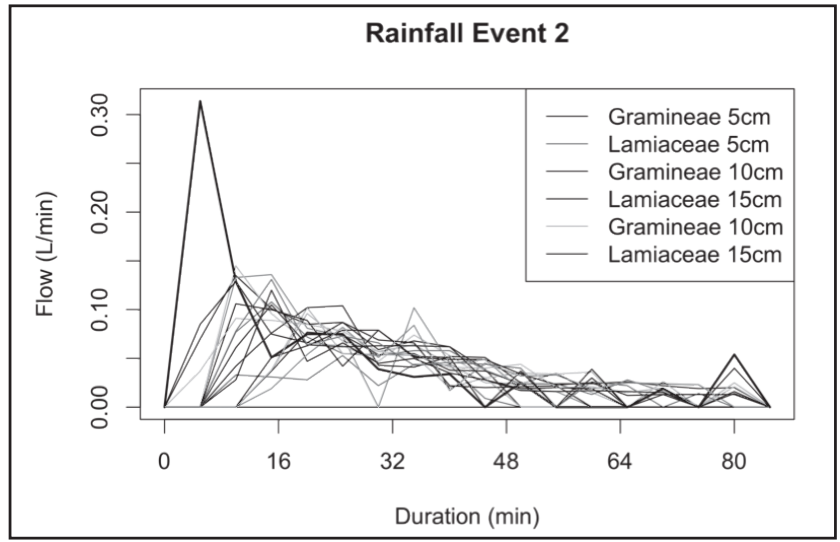

Figure 4. Green roofs answers to second rainfall event

Source: authors

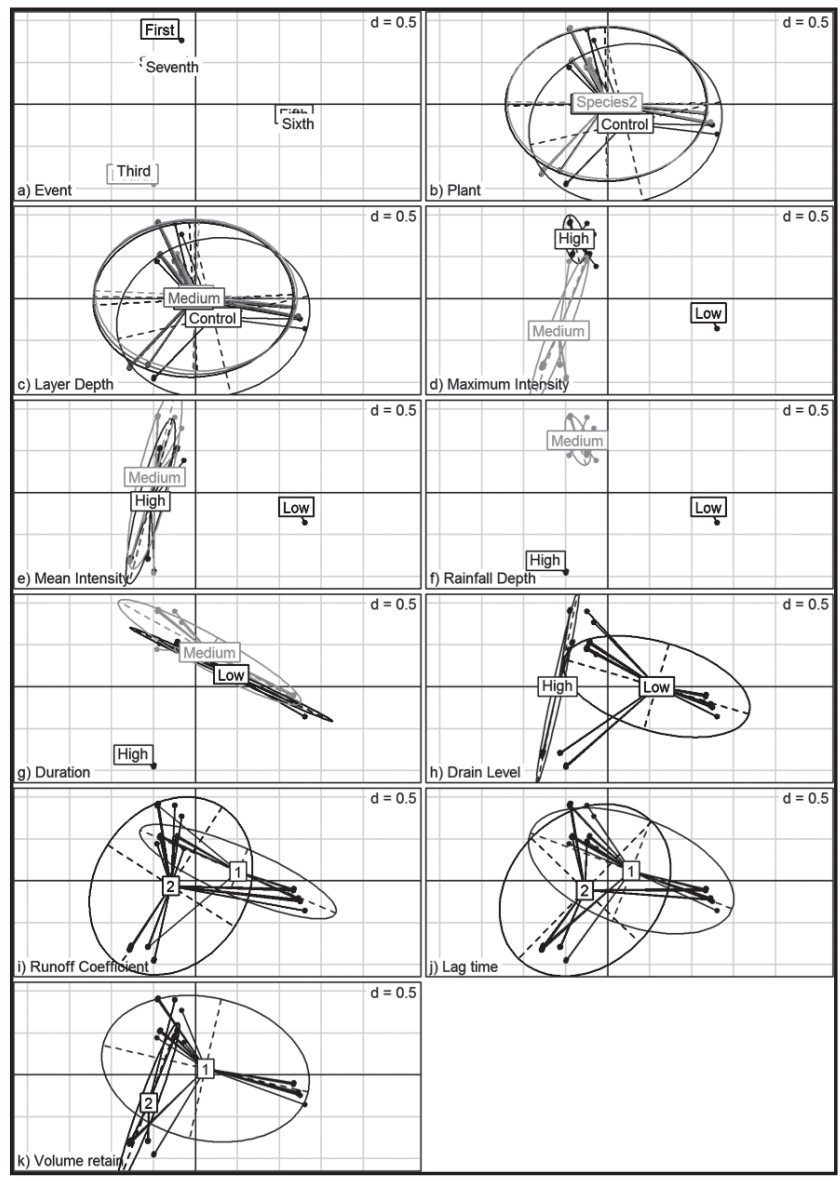

Figure 5. Representation of Event, Plant, Layer Depth, Maximum Intensity, Mean 


\section{Intensity, Rainfall Depth, Runoff Coefficient, Lag-Time, and retain volume variables with $65.5 \%$ portion of explain variance of attenuation phenomena \\ Source: authors}

Table 2 Error: Reference source not found shows seven factors which have a significant influence over $C$ variability. The first and second most important factors are the event duration and the Plant which explains $50.1 \%$ and $29.6 \%$ of the total $C$ variance respectively. The next most important factors are Duration (D), LD, Imax, Level-Drained, Imean, Event, and random errors, which explain together $18.4 \%$ of the total $C$ variance. Also, table 2 evidences that the less important factor corresponds to the random effects, which means that the levels and variables used represent in a good way the variability of $C$, explaining almost all of the $98.1 \%$ of the total $C$ variance.

Table 2. Percentage of Variance Explained in the result of $C, K$, and $V p$ (green boxes are significant $\mathrm{p}$-value $<0.05$ )

\begin{tabular}{|c|c|c|c|}
\hline \multirow{2}{*}{$\begin{array}{l}\text { Independents } \\
\text { variables (input } \\
\text { variables) }\end{array}$} & \multicolumn{3}{|c|}{ Attenuation Variables (output variables) } \\
\hline & $\begin{array}{l}\text { Runoff Coefficient } \\
\text { (C) }\end{array}$ & Lag-Time $(K)$ & $\begin{array}{c}\text { Retain Volume in a } \\
\text { Green roof }\left(V_{p}\right)\end{array}$ \\
\hline Duration & $50.10 \%$ & $0.08 \%$ & $33.32 \%$ \\
\hline Plant & $29.60 \%$ & $40.14 \%$ & $22.39 \%$ \\
\hline Layer Depth & $5.90 \%$ & $1.74 \%$ & $4.80 \%$ \\
\hline $\operatorname{Imax}$ & $4.70 \%$ & $7.41 \%$ & $1.60 \%$ \\
\hline Level Drained & $4.30 \%$ & $40.14 \%$ & $4.28 \%$ \\
\hline Imean & $2.00 \%$ & $2.90 \%$ & $12.56 \%$ \\
\hline Haverage & $1.60 \%$ & $0.14 \%$ & $1.60 \%$ \\
\hline Event & $1.50 \%$ & $1.66 \%$ & $0.47 \%$ \\
\hline Random Error & $0.40 \%$ & $0.69 \%$ & $0.62 \%$ \\
\hline
\end{tabular}

Source: authors

In Figure 6, it can be shown seven additional analyses coupling $\mathrm{C}$ with the following variables: Duration, Level Drained, Plant, Mean Intensity, Level Drained, Event, and Maximum Intensity. A significant difference (all pvalues $<0.05$ ) can be observed for the first and second plots (Figure 6a and Figure 6b) between "Low", "Medium", and "High" levels. In addition, these figures show that the "Medium" levels present the highest variability of $C$. In the Figure $6 c$, it can be observed that there is a significant difference (pvalue $<0.05$ ) between a green roof (with any plant species) and a conventional roof (group= "control"). These results are in agreement with the MCA results shown above. Figure 6d and Figure $6 \mathrm{~g}$ show significant differences between their labels regarding the variability of $C$, and the highest values of $C$ are presented in the label "Medium" intensity. It cannot be observed any difference between Layer Depth labels. Finally, Figure 6f shows significant differences between rainfalls events recorded; furthermore, events 5 and 7 present a higher variability of $C$, while the highest values of $\mathrm{C}$ occurred in the events 3 and 4, which had the major values of duration (178 and 252 minutes). This could indicate that generally a green roof presents a better efficiency in terms of $C$ values for rainfalls with short durations.

In Table 2 and Figure 7 the analysis of variance for the $K$ results are shown. Four factors have significant influence on $K$ variability such as Duration, Level Drained, Imax, and Imean which explain $45.24 \%, 40.14 \%, 7.41 \%$, and $2.9 \%$ respectively. The random error is the next factor in importance, explaining only $0.69 \%$ of $K$ variability. The minors factors in importance are Haverage and Plant, which explain together only $0.22 \%$ of $K$ variability. These results could indicate that Haverage and Plant labels are not good enough to explain the variability of $K$. 


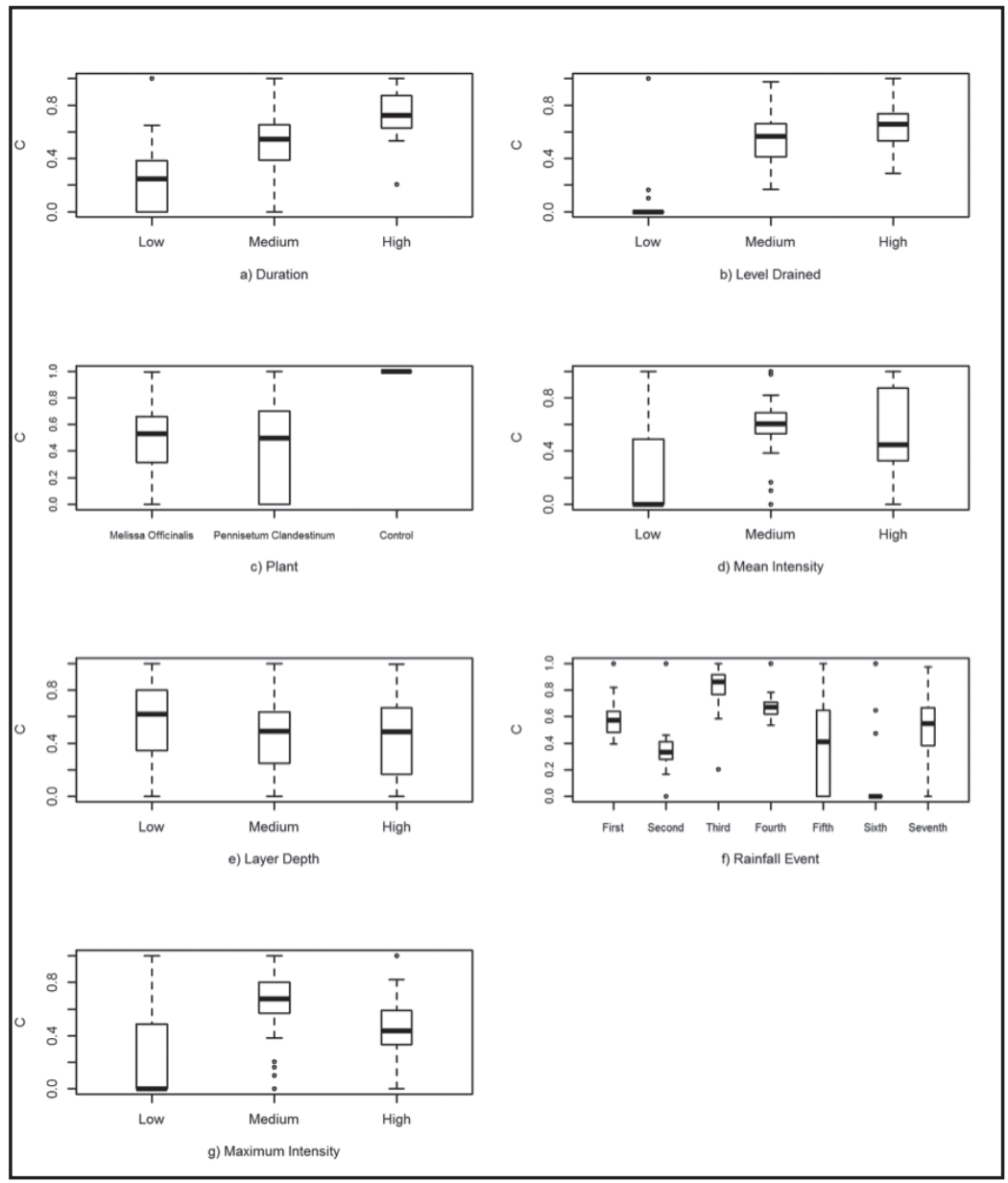

Figure 6 Relations between: C-D, C-Level Drained, C-Plant, C-Imean, C-LD C-Event, and C-Imax for the Coefficient Runoff results

Source: author

In Figure 7, four additional coupled analyses between $K$ and Duration, Level Drained, Maximum Intensity, Mean Intensity can be observed. In Figure $7 \mathrm{a}$ all labels show significant differences, concluding that it exists a linear relation between $K$ and $D$, due to the maximum and minimum $K$ values, which occurred in the events with "low" and "high" durations. Figure $7 \mathrm{~b}$ presents significant differences between all labels, likewise Figure 7c. "Medium" label for Figure 7b and Figure 7c presented the highest lag-times and variability of $K$. Figure $7 \mathrm{~d}$ shows significant differences between "High", "Medium", and "Low" mean intensity levels. This evidences that Mean Intensity and Maximum Intensity have similar behavior regarding their $K$ values, for example the highest $K$ value corresponds to both "Medium" Mean Intensity and Maximum Intensity levels (Figure $7 \mathrm{~b}$ and Figure $7 \mathrm{~d}$ ).

Table 2 shows the percentage of variance explained on the volume retained $(V p)$ results. In Figure 8, six factors can be observed, which have high and significant influence over $V p$ variability, and explain almost all the variability of the phenomenon (more than 97\%). The first factor in importance for $V_{p}$ is the same for $K$ and $C$ : the rainfall duration, which explains more than $33 \%$ of $V p$ variability. These preliminary results 


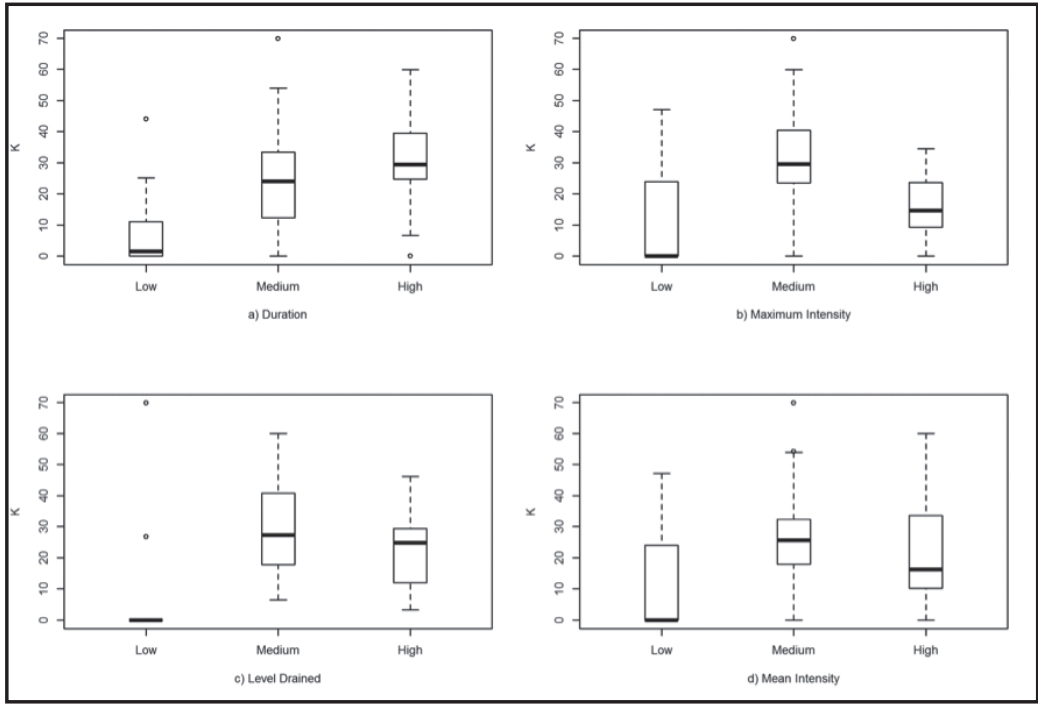

Figure 7 Relations between: K-D, K-Level Drained, K-Imax, and K-Imean, for the

Source: authors Lag-time results

indicate that hydric attenuation has a high influence due to the duration. The following factors in importance are Plant, Imean, Layer-Depth, LD, Event, and random errors which explain together more than $64 \%$ of the variance $(22.39 \%, 12.56 \%, 4.80 \%, 4.28 \%, 0.47 \%$, and $0.62 \%$ respectively). Figure 8 shows that random effects are higher than Haverage, which means that the former does not have significant influence on $V p$, and only explains $0.62 \%$ of $V p$ variance. Haverage is the less important factor in explaining hydric attenuation (see Figure 7 Error: Reference source not found and Error: Reference source not found).

Figure 8 shows six analyses coupling $V p$ with the following variables: Duration, Mean Intensity, Plant, Layer Depth, Rainfall Event, and Level Drained. In the Figure 8a it can be observed that $V p$ varies significantly according to Duration levels, which is confirmed by the t-test resultsError: Reference source not found; $V p$ presents the maximum values for rainfall events with long durations (this is the same behavior as $C$ and $K$ ). Figure $9 \mathrm{~b}$ has significant differences between "Low", "Medium", and "High" Error: Reference source not found. In addition, it follows a linear relation, because the minimum and maximum $V p$ values correspond to "Low" and "High" Mean Intensity labels. Figure 9c has a significant difference between a green roof and a conventional roof ("Control"). Although, the highest values of $V p$ occur in Melissa Officinialis, Figure 9d does not show significant differences between groups; the last results are in agreement with MCA conclusions shown above. Figure 9d presents significant differences between all events. The third and fourth rainfall event presented the highest $V p$ values, possibly due that these events have the longest duration recorded. The second event presented both the highest $V p$ variability and the highest Intensity values. Hence an event with high intensity values could present higher $V p$ variance. Figure 9f has significant differences between the "Low", "Medium", and "High" levels regarding Vp values.

\section{Conclusions}

The results from this study show that event duration is the most significant and most important factor that affects the hydric attenuation phenomena in tropical weather conditions. The kind of plant in the green roof is the second factor in importance, which has a significant influence on runoff coefficient and volume retention $(V p)$; the species Melissa Officinialis presented the highest $V p$ and $C$ 


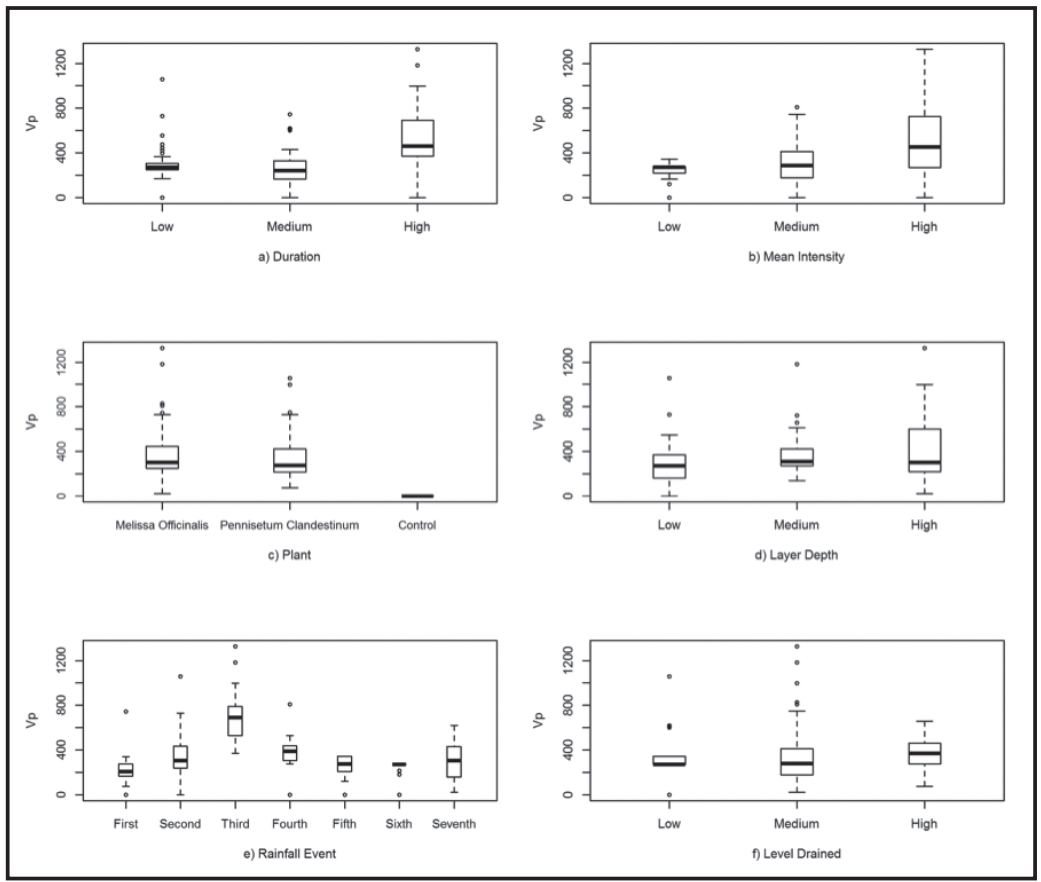

Figure 8 Relations between: Vp-D, Vp-Imean, Vp-Plant, Vp-Layer Deep, Vp-Event,

Source: authors and $V p-L D$ for the retain volume $(V p)$ results

values. Nevertheless, Pennisetum Clandestinum reported the highest $K$ values. Likewise layer depth used in this work $(5 \mathrm{~cm}, 10 \mathrm{~cm}$, and $15 \mathrm{~cm})$ did not present different $V p, C$, and $K$ results, so the difference in attenuation is mainly due to hydrological variables and kind of plant but not to the layer depth of the green roofs. This work found that some event characteristics such as mean and maximum intensity have a significant relation with $C, K$, and $V p$. These results show that a green roof must be designed according to their hydrologic benefits, according to their water retention capabilities and flow peaks attenuations, which are strongly related with hydrologic variables. The present research is affected by: green roof microcosms (at $0.10 \mathrm{~m}^{2}$ ) which were extremely small, and probably have been affected by edge effects (e.g. heating or preferential percolation of runoff) and by the bimodal behavior of the precipitation regime. Phenomenon El Niño and La Niña influences the climatological changes every year. El Nińo is characterized by unusually warm ocean temperatures in the Equatorial Pacific, as opposed to La Niña, which characterized by unusually cold ocean temperatures in the Equatorial Pacific (Mejía, Mesa, Poveda, Vélez, Hoyos, Mantilla... Botero, 1999). Among their consequences, rainfall increases across the whole country which has caused destructive flooding and drought.

We recommend for future experiments including new species and different class of soils, and monitoring theirs responses with higher number of rainfall events. We also recommend measuring more variables which can explain the variability of the whole phenomenon as ADWP (Antecedent Dry Weather Period), slope, soil saturation, temperature, relative humidity, evapotranspiration, and age of the plants, among others. 


\section{References}

Araújo, J., \& González, M. (2010). Metodología para estimar concentraciones de contaminantes en tiempo real a partir de mediciones de turbiedad. Pontificia Universidad Javeriana, Facultad de Ingeniería.

Ascione, F., Bianco, N., de’ Rossi, F., Turni, G., \& Vanoli, G.P. (2013). Green roofs in European climates. Are effective solutions for the energy savings in air-conditioning? Applied Energy, 104, 845-859.

Ballard, B.W., \& Kellagher, R. (2007). The suds Manual. Construction Industry Research \& Information Association (Ciria).

Bates, A. J., Sadler, J. P., \& Mackay, R. (2013). Vegetation development over four years on two green roofs in the UK. Urban Forestry \& Urban Greening, 12, 98-108.

CSQ (2003). Stormwater best management practice handbook. California Stormwater Quality Association.

Dunnett, N., Nagase, A., Booth, R., \& Grime, P. (2008). Influence of vegetation composition on runoff in two simulated green roof experiments. Urban Ecosystems, 11, 385-398.

Getter, K. L., \& Rowe, D. B. (2006). The Role of Extensive Green Roofs in Sustainable Development. Hort Science, $41,1276-1285$

Kasmin, H., Stovin, V. R., \& Hathway, E. A. (2010). Towards a generic rainfall-runoff model for green roofs. Water Science and Technology, 62, 898-905.

Li, S., Gong, H., Zhao, W., \& Liu, J. (2008). Research on Beijing Urban Heat Island and PM10 in the Air (pp. 133136). IEEE.

Marsalek, J. (2007). Urban water cycle processes and interactions. Taylor \& Francis.

Mejía, F., Mesa, O., Poveda, G., Vélez, J., Hoyos, C., Mantilla, R., Barco, J., Cuartas, A., Montoya, M., \& Botero, B. (1999). Distribución espacial y ciclos anual y semianual de la precipitación en Colombia. DYNA, 127, 7-26.

Mentens, J., Raes, D., \& Hermy, M. (2006). Green roofs as a tool for solving the rainwater runoff problem in the urbanized 21st century? Landscape and Urban Planning, 77, 217-226.

New Jersey Department of Environmental Protection (2004). New Jersey Stormwater Best Management Practices Manual. Trenton.

Niemczynowicz, J. (1999). Urban hydrology and water management - present and future challenges. Urban Water, 1, 1-14.

Oberndorfer, E., Lundholm, J., Bass, B., Coffman, R. R., Doshi, H., Dunnett, N., Gaffin, S., KöHler, M., Liu, K. K. Y., \& Rowe, B. (2007). Green Roofs as Urban Ecosystems: Ecological Structures, Functions, and Services. BioScience, 57, 823-833.

Peck, S. W., \& Callaghan, C. (2005). Green roofs: ecological design and construction. Schiffer Pub.

R Core Team (2013). R: A language and environment for statistical computing. Vienna, Austria: R Foundation for Statistical Computing.

Tsang, S. W., \& Jim, C. Y. (2013). A stochastic model to optimize forecast and fulfillment of green roof demand. Urban Forestry \& Urban Greening, 12, 53-60.

U.S Government (1987). Design of Small Dams. U. S. Government.

Werthmann, C., \& C. Architects, A. S. of L. (2007). Green roof: a case study. Princeton Architectural Press. 


\section{Annex}

In this section we presented the Fieldwork data recollected.

Data recollected with experimental mounting.

\begin{tabular}{|c|c|c|c|c|c|c|c|c|c|c|}
\hline Event & Plant & $\begin{array}{l}\text { Layer } \\
\text { Deep }\end{array}$ & $D$ & $\operatorname{Imax}$ & Havarege & $\begin{array}{c}\text { Level } \\
\text { Drained }\end{array}$ & $K$ & C & $V p$ & $V p \%$ \\
\hline 1 & Melissa & 15 & 133 & 29.0 & 12.3 & 13.5 & 6.5 & 0.57 & 177.4 & $20.7 \%$ \\
\hline 1 & Pennisetum & 15 & 133 & 29.0 & 12.3 & 13.8 & 18.2 & 0.50 & 165.0 & $19.2 \%$ \\
\hline 1 & Melissa & 10 & 133 & 29.0 & 12.3 & 11.7 & 17.7 & 0.40 & 269.5 & $31.4 \%$ \\
\hline 1 & Pennisetum & 10 & 133 & 29.0 & 12.3 & 11.5 & 29.7 & 0.47 & 280.0 & $32.6 \%$ \\
\hline 1 & Melissa & 5 & 133 & 29.0 & 12.3 & 10.8 & 34.5 & 0.62 & 317.6 & $37.0 \%$ \\
\hline 1 & Pennisetum & 5 & 133 & 29.0 & 12.3 & 14.0 & 28.6 & 0.44 & 152.5 & $17.8 \%$ \\
\hline 1 & Melissa & 15 & 133 & 29.0 & 12.3 & 11.4 & 15.6 & 0.60 & 286.1 & $33.3 \%$ \\
\hline 1 & Pennisetum & 15 & 133 & 29.0 & 12.3 & 13.8 & 23.7 & 0.61 & 166.1 & $19.4 \%$ \\
\hline 1 & Melissa & 10 & 133 & 29.0 & 12.3 & 14.3 & 30.4 & 0.50 & 138.8 & $16.2 \%$ \\
\hline 1 & Pennisetum & 10 & 133 & 29.0 & 12.3 & 12.4 & 25.3 & 0.57 & 236.7 & $27.6 \%$ \\
\hline 1 & Pennisetum & 5 & 133 & 29.0 & 12.3 & 15.6 & 24.3 & 0.72 & 74.8 & $8.7 \%$ \\
\hline 1 & Melissa & 5 & 133 & 29.0 & 12.3 & 10.3 & 25.2 & 0.43 & 338.3 & $39.4 \%$ \\
\hline 1 & Melissa & 15 & 133 & 29.0 & 12.3 & 2.3 & 7.4 & 0.45 & 743.3 & $86.6 \%$ \\
\hline 1 & Pennisetum & 15 & 133 & 29.0 & 12.3 & 13.6 & 21.3 & 0.59 & 177.1 & $20.6 \%$ \\
\hline 1 & Melissa & 10 & 133 & 29.0 & 12.3 & 12.4 & 21.3 & 0.57 & 232.8 & $27.1 \%$ \\
\hline 1 & Pennisetum & 10 & 133 & 29.0 & 12.3 & 12.9 & 18.8 & 0.82 & 207.9 & $24.2 \%$ \\
\hline 1 & Melissa & 5 & 133 & 29.0 & 12.3 & 12.6 & 30.6 & 0.66 & 227.1 & $26.5 \%$ \\
\hline 1 & Pennisetum & 5 & 133 & 29.0 & 12.3 & 13.5 & 27.2 & 0.73 & 178.7 & $20.8 \%$ \\
\hline 1 & Witness & 0 & 133 & 29.0 & 12.3 & 0.0 & 0.0 & 1.00 & 0.0 & $0.0 \%$ \\
\hline 2 & Melissa & 15 & 83 & 78.6 & 15.9 & 17.6 & 3.2 & 0.43 & 174.9 & $16.5 \%$ \\
\hline 2 & Pennisetum & 15 & 83 & 78.6 & 15.9 & 6.5 & 8.0 & 0.17 & 729.8 & $68.9 \%$ \\
\hline 2 & Melissa & 10 & 83 & 78.6 & 15.9 & 14.4 & 10.8 & 0.33 & 334.2 & $31.6 \%$ \\
\hline 2 & Pennisetum & 10 & 83 & 78.6 & 15.9 & 13.8 & 17.7 & 0.25 & 367.3 & $34.7 \%$ \\
\hline 2 & Melissa & 5 & 83 & 78.6 & 15.9 & 11.6 & 13.6 & 0.31 & 475.9 & $45.0 \%$ \\
\hline 2 & Pennisetum & 5 & 83 & 78.6 & 15.9 & 0.0 & 0.0 & 0.00 & 1058.6 & $100.0 \%$ \\
\hline 2 & Melissa & 15 & 83 & 78.6 & 15.9 & 16.2 & 6.1 & 0.43 & 241.9 & $22.9 \%$ \\
\hline 2 & Pennisetum & 15 & 83 & 78.6 & 15.9 & 16.8 & 9.3 & 0.46 & 213.0 & $20.1 \%$ \\
\hline 2 & Melissa & 10 & 83 & 78.6 & 15.9 & 13.2 & 19.8 & 0.24 & 396.9 & $37.5 \%$ \\
\hline 2 & Pennisetum & 10 & 83 & 78.6 & 15.9 & 15.5 & 12.0 & 0.34 & 278.5 & $26.3 \%$ \\
\hline 2 & Pennisetum & 5 & 83 & 78.6 & 15.9 & 16.5 & 3.7 & 0.41 & 230.0 & $21.7 \%$ \\
\hline 2 & Melissa & 5 & 83 & 78.6 & 15.9 & 12.2 & 11.0 & 0.38 & 444.6 & $42.0 \%$ \\
\hline 2 & Melissa & 15 & 83 & 78.6 & 15.9 & 10.0 & 13.2 & 0.32 & 554.4 & $52.4 \%$ \\
\hline 2 & Pennisetum & 15 & 83 & 78.6 & 15.9 & 15.9 & 9.6 & 0.34 & 260.3 & $24.6 \%$ \\
\hline 2 & Melissa & 10 & 83 & 78.6 & 15.9 & 12.7 & 21.1 & 0.27 & 422.7 & $39.9 \%$ \\
\hline
\end{tabular}




\begin{tabular}{|c|c|c|c|c|c|c|c|c|c|c|}
\hline Event & Plant & $\begin{array}{l}\text { Layer } \\
\text { Deep }\end{array}$ & $D$ & $\operatorname{Imax}$ & Havarege & $\begin{array}{c}\text { Level } \\
\text { Drained }\end{array}$ & $K$ & $C$ & $V p$ & $V p \%$ \\
\hline 2 & Pennisetum & 10 & 83 & 78.6 & 15.9 & 17.7 & 11.1 & 0.29 & 167.5 & $15.8 \%$ \\
\hline 2 & Melissa & 5 & 83 & 78.6 & 15.9 & 15.0 & 12.0 & 0.33 & 304.6 & $28.8 \%$ \\
\hline 2 & Pennisetum & 5 & 83 & 78.6 & 15.9 & 16.1 & 11.0 & 0.42 & 248.4 & $23.5 \%$ \\
\hline 2 & Witness & 0 & 83 & 78.6 & 15.9 & 0.0 & 0.0 & 1.00 & 0.0 & $0.0 \%$ \\
\hline 3 & Melissa & 15 & 178 & 22.4 & 11.4 & 12.4 & 43.6 & 0.87 & 828.7 & $57.0 \%$ \\
\hline 3 & Pennisetum & 15 & 178 & 22.4 & 11.4 & 14.0 & 38.5 & 0.86 & 749.0 & $51.5 \%$ \\
\hline 3 & Pennisetum & 10 & 178 & 22.4 & 11.4 & 17.6 & 25.1 & 0.58 & 568.4 & $39.1 \%$ \\
\hline 3 & Melissa & 5 & 178 & 22.4 & 11.4 & 18.0 & 28.1 & 0.80 & 548.9 & $37.8 \%$ \\
\hline 3 & Pennisetum & 5 & 178 & 22.4 & 11.4 & 21.6 & 14.9 & 0.90 & 370.3 & $25.5 \%$ \\
\hline 3 & Melissa & 15 & 178 & 22.4 & 11.4 & 17.7 & 31.6 & 0.99 & 561.8 & $38.6 \%$ \\
\hline 3 & Pennisetum & 15 & 178 & 22.4 & 11.4 & 14.0 & 40.5 & 0.90 & 748.0 & $51.4 \%$ \\
\hline 3 & Melissa & 10 & 178 & 22.4 & 11.4 & 5.4 & 60.0 & 0.88 & 1182.1 & $81.3 \%$ \\
\hline 3 & Pennisetum & 10 & 178 & 22.4 & 11.4 & 19.7 & 29.4 & 0.75 & 464.1 & $31.9 \%$ \\
\hline 3 & Pennisetum & 5 & 178 & 22.4 & 11.4 & 20.4 & 23.4 & 0.94 & 430.9 & $29.6 \%$ \\
\hline 3 & Melissa & 5 & 178 & 22.4 & 11.4 & 14.4 & 40.0 & 0.86 & 730.9 & $50.3 \%$ \\
\hline 3 & Melissa & 15 & 178 & 22.4 & 11.4 & 2.5 & 52.4 & 0.20 & 1328.5 & $91.4 \%$ \\
\hline 3 & Pennisetum & 15 & 178 & 22.4 & 11.4 & 9.0 & 44.9 & 0.78 & 999.3 & $68.7 \%$ \\
\hline 3 & Melissa & 10 & 178 & 22.4 & 11.4 & 14.5 & 42.1 & 0.70 & 722.7 & $49.7 \%$ \\
\hline 3 & Pennisetum & 10 & 178 & 22.4 & 11.4 & 15.9 & 35.5 & 1.00 & 657.3 & $45.2 \%$ \\
\hline 3 & Melissa & 5 & 178 & 22.4 & 11.4 & 18.8 & 25.2 & 0.97 & 508.0 & $34.9 \%$ \\
\hline 4 & Witness & 0 & 178 & 22.4 & 11.4 & 0.0 & 0.0 & 1.00 & 0.0 & $0.0 \%$ \\
\hline 4 & Melissa & 15 & 252 & 22.2 & 13.6 & 22.7 & 27.7 & 0.66 & 323.6 & $22.1 \%$ \\
\hline 4 & Pennisetum & 15 & 252 & 22.2 & 13.6 & 22.6 & 21.1 & 0.69 & 328.0 & $22.4 \%$ \\
\hline 4 & Melissa & 10 & 252 & 22.2 & 13.6 & 23.7 & 28.1 & 0.68 & 276.1 & $18.8 \%$ \\
\hline 4 & Pennisetum & 10 & 252 & 22.2 & 13.6 & 21.8 & 32.3 & 0.63 & 367.6 & $25.1 \%$ \\
\hline 4 & Melissa & 5 & 252 & 22.2 & 13.6 & 23.5 & 29.9 & 0.78 & 285.9 & $19.5 \%$ \\
\hline 4 & Pennisetum & 5 & 252 & 22.2 & 13.6 & 20.1 & 13.0 & 0.62 & 453.2 & $30.9 \%$ \\
\hline 4 & Melissa & 15 & 252 & 22.2 & 13.6 & 22.1 & 15.1 & 0.61 & 356.9 & $24.4 \%$ \\
\hline 4 & Pennisetum & 15 & 252 & 22.2 & 13.6 & 20.8 & 24.7 & 0.70 & 420.0 & $28.7 \%$ \\
\hline 4 & Melissa & 10 & 252 & 22.2 & 13.6 & 19.4 & 39.1 & 0.63 & 492.4 & $33.6 \%$ \\
\hline 4 & Pennisetum & 10 & 252 & 22.2 & 13.6 & 20.7 & 32.8 & 0.60 & 424.0 & $28.9 \%$ \\
\hline 4 & Pennisetum & 5 & 252 & 22.2 & 13.6 & 20.0 & 25.1 & 0.69 & 461.2 & $31.5 \%$ \\
\hline 4 & Melissa & 5 & 252 & 22.2 & 13.6 & 21.4 & 24.8 & 0.73 & 388.8 & $26.5 \%$ \\
\hline 4 & Melissa & 15 & 252 & 22.2 & 13.6 & 13.1 & 54.2 & 0.56 & 808.9 & $55.2 \%$ \\
\hline 4 & Pennisetum & 15 & 252 & 22.2 & 13.6 & 23.7 & 25.6 & 0.72 & 274.6 & $18.7 \%$ \\
\hline 4 & Melissa & 10 & 252 & 22.2 & 13.6 & 18.6 & 46.2 & 0.67 & 529.1 & $36.1 \%$ \\
\hline 4 & Pennisetum & 10 & 252 & 22.2 & 13.6 & 20.8 & 31.4 & 0.58 & 422.0 & $28.8 \%$ \\
\hline 4 & Melissa & 5 & 252 & 22.2 & 13.6 & 21.2 & 6.6 & 0.53 & 401.2 & $27.4 \%$ \\
\hline
\end{tabular}




\begin{tabular}{|c|c|c|c|c|c|c|c|c|c|c|}
\hline Event & Plant & $\begin{array}{l}\text { Layer } \\
\text { Deep }\end{array}$ & $D$ & $\operatorname{Imax}$ & Havarege & $\begin{array}{c}\text { Level } \\
\text { Drained }\end{array}$ & $K$ & $C$ & $V p$ & $V p \%$ \\
\hline 4 & Witness & 0 & 252 & 22.2 & 13.6 & 0.0 & 0.0 & 1.00 & 0.0 & $0.0 \%$ \\
\hline 5 & Melissa & 15 & 109 & 13.7 & 3.6 & 2.7 & 17.1 & 0.96 & 204.1 & $59.7 \%$ \\
\hline 5 & Pennisetum & 15 & 109 & 13.7 & 3.6 & 0.0 & 0.0 & 0.00 & 342.2 & $100.0 \%$ \\
\hline 5 & Melissa & 10 & 109 & 13.7 & 3.6 & 3.5 & 12.4 & 0.65 & 163.9 & $47.9 \%$ \\
\hline 5 & Pennisetum & 10 & 109 & 13.7 & 3.6 & 0.0 & 0.0 & 0.00 & 342.2 & $100.0 \%$ \\
\hline 5 & Melissa & 5 & 109 & 13.7 & 3.6 & 0.9 & 41.2 & 0.35 & 299.0 & $87.4 \%$ \\
\hline 5 & Pennisetum & 5 & 109 & 13.7 & 3.6 & 4.4 & 23.9 & 0.79 & 120.8 & $35.3 \%$ \\
\hline 5 & Melissa & 15 & 109 & 13.7 & 3.6 & 2.5 & 27.3 & 0.65 & 218.3 & $63.8 \%$ \\
\hline 5 & Pennisetum & 15 & 109 & 13.7 & 3.6 & 0.0 & 0.0 & 0.00 & 342.2 & $100.0 \%$ \\
\hline 5 & Melissa & 10 & 109 & 13.7 & 3.6 & 1.4 & 10.1 & 0.45 & 273.5 & $79.9 \%$ \\
\hline 5 & Pennisetum & 10 & 109 & 13.7 & 3.6 & 2.6 & 27.7 & 0.49 & 209.5 & $61.2 \%$ \\
\hline 5 & Pennisetum & 5 & 109 & 13.7 & 3.6 & 3.5 & 22.4 & 0.61 & 164.3 & $48.0 \%$ \\
\hline 5 & Melissa & 5 & 109 & 13.7 & 3.6 & 1.0 & 47.1 & 0.29 & 291.3 & $85.1 \%$ \\
\hline 5 & Melissa & 15 & 109 & 13.7 & 3.6 & 0.0 & 0.0 & 0.00 & 342.2 & $100.0 \%$ \\
\hline 5 & Pennisetum & 15 & 109 & 13.7 & 3.6 & 1.1 & 46.3 & 0.41 & 288.9 & $84.4 \%$ \\
\hline 5 & Melissa & 10 & 109 & 13.7 & 3.6 & 0.0 & 0.0 & 0.00 & 342.2 & $100.0 \%$ \\
\hline 5 & Pennisetum & 10 & 109 & 13.7 & 3.6 & 0.0 & 0.0 & 0.00 & 342.2 & $100.0 \%$ \\
\hline 5 & Melissa & 5 & 109 & 13.7 & 3.6 & 1.9 & 34.6 & 0.31 & 247.8 & $72.4 \%$ \\
\hline 5 & Pennisetum & 5 & 109 & 13.7 & 3.6 & 1.9 & 44.0 & 0.65 & 246.5 & $72.0 \%$ \\
\hline 5 & Witness & 0 & 109 & 13.7 & 3.6 & 0.0 & 0.0 & 1.00 & 0.0 & $0.0 \%$ \\
\hline 6 & Melissa & 15 & 74 & 13.9 & 3.9 & 0.0 & 0.0 & 0.00 & 269.7 & $100.0 \%$ \\
\hline 6 & Pennisetum & 15 & 74 & 13.9 & 3.9 & 0.0 & 0.0 & 0.00 & 269.7 & $100.0 \%$ \\
\hline 6 & Melissa & 10 & 74 & 13.9 & 3.9 & 1.1 & 44.1 & 0.65 & 214.1 & $79.4 \%$ \\
\hline 6 & Pennisetum & 10 & 74 & 13.9 & 3.9 & 0.0 & 0.0 & 0.00 & 269.7 & $100.0 \%$ \\
\hline 6 & Melissa & 5 & 74 & 13.9 & 3.9 & 0.0 & 0.0 & 0.00 & 269.7 & $100.0 \%$ \\
\hline 6 & Pennisetum & 5 & 74 & 13.9 & 3.9 & 0.0 & 0.0 & 0.00 & 269.7 & $100.0 \%$ \\
\hline 6 & Melissa & 15 & 74 & 13.9 & 3.9 & 1.8 & 25.1 & 0.47 & 178.7 & $66.3 \%$ \\
\hline 6 & Pennisetum & 15 & 74 & 13.9 & 3.9 & 0.0 & 0.0 & 0.00 & 269.7 & $100.0 \%$ \\
\hline 6 & Melissa & 10 & 74 & 13.9 & 3.9 & 0.0 & 0.0 & 0.00 & 269.7 & $100.0 \%$ \\
\hline 6 & Pennisetum & 10 & 74 & 13.9 & 3.9 & 0.0 & 0.0 & 0.00 & 269.7 & $100.0 \%$ \\
\hline 6 & Pennisetum & 5 & 74 & 13.9 & 3.9 & 0.0 & 0.0 & 0.00 & 269.7 & $100.0 \%$ \\
\hline 6 & Melissa & 5 & 74 & 13.9 & 3.9 & 0.0 & 0.0 & 0.00 & 269.7 & $100.0 \%$ \\
\hline 6 & Melissa & 15 & 74 & 13.9 & 3.9 & 0.0 & 0.0 & 0.00 & 269.7 & $100.0 \%$ \\
\hline 6 & Pennisetum & 15 & 74 & 13.9 & 3.9 & 0.0 & 0.0 & 0.00 & 269.7 & $100.0 \%$ \\
\hline 6 & Melissa & 10 & 74 & 13.9 & 3.9 & 0.0 & 0.0 & 0.00 & 269.7 & $100.0 \%$ \\
\hline 6 & Pennisetum & 10 & 74 & 13.9 & 3.9 & 0.0 & 0.0 & 0.00 & 269.7 & $100.0 \%$ \\
\hline 6 & Melissa & 5 & 74 & 13.9 & 3.9 & 0.0 & 0.0 & 0.00 & 269.7 & $100.0 \%$ \\
\hline 6 & Pennisetum & 5 & 74 & 13.9 & 3.9 & 0.0 & 0.0 & 0.00 & 269.7 & $100.0 \%$ \\
\hline
\end{tabular}




\begin{tabular}{|c|c|c|c|c|c|c|c|c|c|c|}
\hline Event & Plant & $\begin{array}{l}\text { Layer } \\
\text { Deep }\end{array}$ & $D$ & $\operatorname{Imax}$ & Havarege & $\begin{array}{c}\text { Level } \\
\text { Drained }\end{array}$ & $K$ & $C$ & $V p$ & $V p \%$ \\
\hline 6 & Witness & 0 & 74 & 13.9 & 3.9 & 0.0 & 0.0 & 1.00 & 0.0 & $0.0 \%$ \\
\hline 7 & Melissa & 15 & 164 & 16.2 & 7.6 & 11.9 & 12.1 & 0.67 & 20.9 & $3.4 \%$ \\
\hline 7 & Pennisetum & 15 & 164 & 16.2 & 7.6 & 0.4 & 69.8 & 0.17 & 598.7 & $96.5 \%$ \\
\hline 7 & Melissa & 10 & 164 & 16.2 & 7.6 & 9.2 & 29.6 & 0.52 & 158.3 & $25.5 \%$ \\
\hline 7 & Pennisetum & 10 & 164 & 16.2 & 7.6 & 5.5 & 47.6 & 0.38 & 344.0 & $55.4 \%$ \\
\hline 7 & Melissa & 5 & 164 & 16.2 & 7.6 & 6.4 & 53.9 & 0.53 & 300.8 & $48.5 \%$ \\
\hline 7 & Pennisetum & 5 & 164 & 16.2 & 7.6 & 9.6 & 16.0 & 0.80 & 138.0 & $22.2 \%$ \\
\hline 7 & Melissa & 15 & 164 & 16.2 & 7.6 & 11.9 & 12.7 & 0.98 & 23.8 & $3.8 \%$ \\
\hline 7 & Pennisetum & 15 & 164 & 16.2 & 7.6 & 0.0 & 0.0 & 0.00 & 620.5 & $100.0 \%$ \\
\hline 7 & Melissa & 10 & 164 & 16.2 & 7.6 & 3.8 & 51.2 & 0.42 & 430.3 & $69.3 \%$ \\
\hline 7 & Pennisetum & 10 & 164 & 16.2 & 7.6 & 8.8 & 35.9 & 0.78 & 175.7 & $28.3 \%$ \\
\hline 7 & Pennisetum & 5 & 164 & 16.2 & 7.6 & 9.1 & 21.0 & 0.70 & 162.4 & $26.2 \%$ \\
\hline 7 & Melissa & 5 & 164 & 16.2 & 7.6 & 6.2 & 38.8 & 0.64 & 310.1 & $50.0 \%$ \\
\hline 7 & Melissa & 15 & 164 & 16.2 & 7.6 & 6.0 & 42.6 & 0.56 & 317.3 & $51.1 \%$ \\
\hline 7 & Pennisetum & 15 & 164 & 16.2 & 7.6 & 0.0 & 0.0 & 0.00 & 620.5 & $100.0 \%$ \\
\hline 7 & Melissa & 10 & 164 & 16.2 & 7.6 & 0.2 & 26.7 & 0.10 & 612.2 & $98.7 \%$ \\
\hline 7 & Pennisetum & 10 & 164 & 16.2 & 7.6 & 6.2 & 47.0 & 0.57 & 309.7 & $49.9 \%$ \\
\hline 7 & Melissa & 5 & 164 & 16.2 & 7.6 & 8.1 & 32.5 & 0.54 & 211.6 & $34.1 \%$ \\
\hline 7 & Pennisetum & 5 & 164 & 16.2 & 7.6 & 9.7 & 29.1 & 0.59 & 134.6 & $21.7 \%$ \\
\hline
\end{tabular}

Source: authors 